\title{
Pengaruh Administrasi Perpajakan, Kualitas Layanan Fiskus, Terhadap Perilaku Wajib Pajak Dan Kepatuhan Wajib Pajak (Studi Pada Wajib Pajak Badan Di Kantor Pelayanan Pajak Kota Malang Selatan 2015)
}

\author{
Muhammad Yusril ${ }^{\mathbf{1}}$ M.Awaluddin ${ }^{2}$ \\ ${ }^{1}$ Prodi Administrasi Bisnis, Universitas Muhammadiyah Mataram, Indonesia \\ ${ }^{2}$ Prodi Administrasi Publik, Universitas Muhammadiyah Mataram, Indonesia
}

\section{INFO ARTIKEL}

\section{Riwayat Artikel:}

Diterima: $10-02-2018$

Disetujui: 11-03-2018

\section{Kata Kunci:}

1. Pajak

2. Kepatuhan wajib pajak

3. Administrasi Perpajakan

4. Kualitas layanan fiskus

5. Perilaku wajib pajak

\begin{abstract}
ABSTRAK
Abstrak: Penelitian ini dilatar belakangi oleh adanya tuntutan terhadap dilakukannya upaya dalam peningkatan penerimaan negara terutama di sektor perpajakan, baik dari segala perbaikan serta perubahan yang mendasar di segala aspek perpajakan. Salah satu tuntutan yang dimaksud adalah tuntutan kepatuhan wajib pajak. Kepatuhan wajib pajak di dalam melaksanakan kewajiban perpajakannya tidak lepas dari peran sistem administrasi perpajakan yang telah ditetapkan pemerintah dan juga sikap dari masyarakat wajib pajak itu sendiri. Selain itu, upaya yang tidak kalah pentingnya adalah upaya pemerintah di dalam meningkatkan kualitas pelayanan dari aparat pajak sehingga diharapkan akan berdampak pada kepatuhan wajib pajak. Penelitian ini bertujuan untuk mengetahui pengaruh administrasi perpajakan dan kualitas layanan fiskus terhadap kepatuhan wajib pajak yang dimediasi oleh perilaku wajib pajak.

Penelitian ini merupakan penelitian eksplanatori dengan
\end{abstract} menggunakan pendekatan kuantitatif. Data ini menggunakan sumber data primer yang berasal dari penggisian kuesioner dan wawancara dengan wajib pajak badan yang terdaftar di kantor pelayanan pajak Malang selatan dan dibantu dengan berbagai data sekunder yang relevan. Data dikumpulkan menggunakan metode accidental sampling dan dianalisis dengan menggunakan teknik analisis jalur (Path Analysis) dalam aplikasi SPSS versi 20.

Hasil penelitian menunjukkan bahwa dari baik administrasi perpajakan, kualitas layanan fiskus, dan perilaku wajib pajak secara langsung memiliki pengaruh yang signifikan terhadap kepatuhan wajib pajak. Hasil penelitian ini juga menunjukkan bahwa variabel administrasi perpajakan dan kualitas layanan fiskus memiliki pengaruh signifikan ketika dimediasi melalui variabel perilaku wajib pajak. Oleh karena itu, berdasarkan penelitian yang telah dilakukan, maka seluruh hipotesis yang dibangun di dalam penelitian ini dapat diterima. Berbagai keterbatasan yang masih dialami oleh peneliti diharapkan menjadi sebuah tantangan bagi penelitian selanjutnya untuk mendapatkan hasil penelitian yang lebih menggambarkan faktor-faktor yang mempengaruhi terjadinya peningkatan atas kepatuhan yang dilakukan oleh wajib pajak badan. 
Keyword:

1. taxes,

2. taxpayer compliance,

3. the tax administration,

4. the quality of service performed by the tax authorities,

5. the behavior of taxpayer.

\section{Abstract}

The research was motivated by the demands of the increasing government revenues, especially in the sector of taxation, both form all repair and fundamental change in all aspects of taxation. One of them is the demans on taxpayer compliance. Taxpayer compliance in implementing the tax obligations can not be separated from the role of the tax administration system that has been determined by the government and also the attitude of the public taxpayer itself. In addition, one of the efforts that are not less important is the government's efforts in improving taxpayer satisfaction through improved quality of service performed by the tax authorities which is expected to have an impact on taxpayer compliance. This study aims to determine the effect of the tax administration and the quality of service performed by tax authorities to taxpayer compliance is mediated by the behavior of taxpayer.

This research is explanatory reseach using a quantitative approach. This data using primary data sources are derived from filling the questionnaire and interviews whit taxpayer that registered in tax office south Malang and assisted with a variety of relevant secondary data. Data were collected using accidental sampling method and analyzed by using path analysis in SPSS version 20.

The results showed that both the tax administration, the quality of service performed by the tax authorities, and the behavior of taxpayer directly have a significant impact on taxpayer compliance. The results also show that the tax administration and the the quality of service performed by the tax authorities has a significant effect when mediated through the behavior of taxpayer. Therefore, based on the reseach that has been done, then all hypotheses that have been constructed in this study is acceptable. Various limitations faced by researchers is expected to become a challenge for future research to obtain reseach results further illustrate the factor that influence the increase taxpayer compliance.

\section{Latar Belakang}

Pajak merupakan sumber penerimaan negara yang memiliki peranan sangat penting dari waktu ke waktu. Hal ini terkait dengan fungsi pajak itu sendiri yaitu sebagai fungsi budgetair dan regulerend. Fungsi budgetair, yakni pajak merupakan sumber penerimaan negara yang digunakan untuk membiayai pengeluaran rutin pemerintah. Fungsi regulerend, pajak digunakan sebagai alat untuk mengatur atau melaksana-kan kebijakan pemerintah dalam bidang sosial, ekonomi, politik, kebudayaan, dan hankam (Mardiasmo, 2003).

Pada awal tahun 1984, sejak dimulainya tax reform sistem perpajakan di Indonesia berubah dari official assessment system menjadi self assessment system. Dalam official assessment system tanggung jawab pemungutan terletak sepenuh-nya pada pemerintah, sedangkan dalam self assessment system Wajib Pajak diberi kepercayaan penuh untuk menghitung, memperhitung-kan, membayar/ menyetor dan me-laporkan besarnya pajak yang terhutang sesuai dengan jangka waktu yang telah ditentukan dalam peraturan perundang-undangan per-pajakan. Nampak jelas disini bahwa dalam self assessment system Wajib Pajak lebih dipandang sebagai subjek bukan sebagai objek pajak. Sebagai konsekuensi dari perubahan ini Direktorat Jenderal Pajak (DJP) berkewajiban untuk melakukan pelayanan, pengawasan, pembinaan, dan penerapan sanksi pajak.

Untuk mewujudkan self assess-ment system dituntut kepatuhan Wajib Pajak itu sendiri. Namun, 
dalam kenyataannya belum semua potensi pajak yang ada dapat digali. Sebab masih banyak Wajib Pajak yang belum memiliki kesadaran akan betapa pentingnya pemenuhan kewajiban perpajakan baik bagi negara maupun bagi mereka sendiri sebagai warga negara yang baik.

Kepatuhan wajib pajak memegang peranan penting untuk menentukan jumlah pajak yang berhasil dipungut oleh Direktorat Jenderal Pajak (DJP). Semakin tinggi kepatuhan wajib pajak, semakin berdampak pada peningkatan pajak. Pencapaian target penerimaan pajak dapat dimanfaatkan sebagai sumber dana bagi pemerintah yang digunakan untuk membiayai pengeluaranpengeluaran negara. .

Salah satu indikator rendahnya tingkat kepatuhan wajib pajak adalah dapat dilihat dari beberapa faktor yakni salah satunya dari seberapa besar jumlah surat teguran dan surat paksaan yang di keluarkan oleh DJP setiap tahunnya. Salah satu contoh yang menjadi pusat fokus peneliti dalam penelitian ini adalah jumlah surat teguran yang dikeluarkan oleh kantor KPP Malang selatan.

Tabel 1. Daftar Tabel Tingkat Kepatuhan

\begin{tabular}{|l|c|r|r|r|c|}
\hline Tahun & $\begin{array}{c}\text { Wajib } \\
\text { Pajak } \\
\text { Terdaftar }\end{array}$ & $\begin{array}{c}\text { Wajib Pajak } \\
\text { Efektif }\end{array}$ & $\begin{array}{c}\text { Wajib Pajak } \\
\text { Non Efektif }\end{array}$ & $\begin{array}{c}\text { Surat } \\
\text { Tegu-ran }\end{array}$ & $\begin{array}{c}\text { Tingkat } \\
\text { Kepatuhan }\end{array}$ \\
\hline 2011 & 59.432 & 39.177 & 20.255 & 886 & $66 \%$ \\
\hline 2012 & 61.110 & 38.105 & 23.005 & 916 & $62 \%$ \\
\hline 2013 & 62.384 & 40.287 & 22.097 & 968 & $56,86 \%$ \\
\hline \multicolumn{6}{|c|}{ Sumber $:$ http://www.pajak.go.id (2013) }
\end{tabular}

Dari data tabel diatas dapat kita lihat bahwa, adanya peningkatan setiap tahunnya jumlah surat teguran yang dikeluarkan oleh KPP Malang selatan dan menurunnya tingkat kepatuhan wajib pajak dari tahun 2011-2013, yang artinya disini adanya permasalahan yang menarik untuk diteliti oleh peneliti dan inilah alasan mendasarkan kenapa peneliti mengangkat judul pengaruh administrasi pajak, kualitas pelayanan fiskus terhadap perilaku wajib pajak dan kepatuhan wajib pajak badan (studi pada KPP Malang Selatan).

Menilai keberhasilan penerima-an pajak, perlu diingat beberapa sasaran administrasi perpajakan, seperti : 1) meningkatkan kepatuhan para pembayar pajak, dan 2) melaksanakan ketentuan perpajakan secara menyeluruh dan seragam untuk mendapatkan penerimaan maksimal dengan biaya yang optimal. Menurut Chaizi (2004) dalam Rapina, Jerry dan Yeni (2011), pengukuran efektifitas administrasi perpajakan yang lebih akurat adalah dengan mengukur berapa besarnya jurang kepatuhan (tax gap), yaitu selisih antara penerimaan yang sesungguh-nya dengan pajak potensial dengan tingkat kepatuhan dari masing-masing sektor perpajakan.

Kepatuhan wajib pajak (tax compliance) dapat diidentifikasi dari kepatuhan wajib pajak dalam mendaftarkan diri, kepatuhan untuk menyetorkan kembali surat pem-beritahuan (SPT), kepatuhan dalam memperhitungkan dan membayar pajak terutang, dan kepatuhan dalam pembayaran tunggakan. Isu ke-patuhan menjadi penting karena ketidakpatuhan secara bersamaan akan menimbulkan upaya meng-hindari pajak, seperti tax evosion dan tax avoidance, yang mengakibatkan berkurangnya penerimaan negara dari sektor perpajakan. Pada hakekatnya kepatuhan wajib pajak dipengaruhi oleh kondisi sistem administrasi perpajakan yang meliputi tax service dan tax enforcement. Perbaikan administrasi perpajakan sendiri diharapkan dapat mendorong kepatuahan wajib pajak.

Pemungutan pajak bukan pekerjaan mudah, karena disamping diperlukan peran aktif dari petugas perpajakan, juga dituntut kesadaran dari wajib pajak itu sendiri. Kemauan wajib pajak dalam membayar pajak antara lain, karena asas perpajakan yaitu bahwa hasil pemunggutan pajak tersebut tidak secara langsung dapat dinikmati oleh para wajib pajak. Hal ini terjadi karena wajib pajak tidak merasakan wujud kongkret imbalan dari uang yang dikeluarkan untuk membayar pajak.

Penelitian Caro dan Garcia (2007), menunjukkan bahwa indikator kualitas pelayanan ditentukan oleh tiga faktor yaitu kualitas interaksi, kualitas lingkungan fisik,dan hasil kualitas pelayanan. Yang dimaksud dengan kualitas interaksi di atas adalah tentang bagaimana cara fiskus dalam mengkomunikasikan pelayanan pajak kepada wajib pajak sehingga wajib pajak puas terhadap pelayanannya. Kualitas lingkungan fisik tentang bagaimana peranan kualitas lingkungan dari kantor pajak sendiri dalam melayani wajib pajak. Hasil kualitas pelayanan adalah apabila pelayanan dari fiskus dapat memberikan kepuasan terhadap wajib pajak maka persepsi wajib pajak terhadap fiskus akan baik sehingga dapat meningkatkan kepatuhan wajib pajak.

Kata kualitas mengandung banyak definisi dan makna karena orang yang berbeda akan mengartikannya secara berbeda, seperti kesesuaian dengan persyaratan atau tuntutan, kecocokan untuk pemakaian perbaiakan, pemenuhan berkelanjutan, bebas dari kerusakan atau cacat, pemenuhan kebutuhan pelanggan, melakukan segala sesuatu yang membahagiakan. Sedangkan dalam perspektif TQM (Total Quality Management) kualitas dipandang secara lebih luas, 
yaitu tidak hanya aspek hasil yang ditekankan tetapi juga meliputi proses, lingkungan dan manusia. Kualitas merupakan suatu kondisi dinamis yang berhubungan dengan produk, jasa, manusia, proses dan lingkungan yang memenuhi atau melebihi harapan.

Faktor yang menyebabkan rendahnya tax ratio adalah rendahnya pendapatan per kapita, tingkat kepatuhan wajib pajak yang masih rendah (kesadaran masya-rakat akan kewajiban perpajakan masih sangat rendah), wajib pajak dalam melaporkan peredaran usaha dan penghasilan bersihnya belum dilakukan secara transparan, dan tingkat efesiensi administrasi perpajakan yang belum maksimal (Zaini, 2001). Rendahnya kesadaran masyarakat akan kewajiban per-pajakan ini seringkali disebabkan oleh karena ketidaktahuan masya-rakat akan aturan perpajakan.

Rendahnya ratio pajak menunjukkan belum tergalinya potensi penerimaan pajak secara optimal. Soemitro dalam Yurzal dan Makhfatih (2000), menyatakan bahwa ketidak efisien pemungutan pajak disebabkan oleh kelemahan aparatur pajak, administrasi dan kesadaran wajib pajak yang rendah. Sedangkan Mangkoesoebroto dalam Yurzal dan Makhfatih (2000), menyatakan tidak efektifnya peraturan perpajakan disebabkan lemahnya sistem hukum dan sistem akuntansi di Indonesia.

Perilaku dapat diartikan suatu respon organisme atau seseorang terhadap rangsangan dari luar subjek tersebut. Perilaku diartikan sebagai suatu aksi -reaksi organisme terhadap lingkungannya. Perilaku baru terjadi apabila ada sesuatu yang diperlukan untuk menimbulkan reaksi, yakni yang disebut rangsangan. Gibson et al (1996) menyatakan bahwa perilaku individu adalah segala sesuatu yang dilakukan seseorang, seperti berbicara, berfikir, atau tindakan dari suatu sikap. Sedangkan perilaku menurut Kurt Levin dalam Hardiningsih (1996), perilaku individu merupakan fungsi dari interaksi antar individu yang bersangkutan dengan lingkungan.

\section{Tinjauan Pustaka}

a. Administrasi Perpajakan Terhadap Perilaku Wajib Pajak

Administrasi pajak merupakan cara-cara atau prosedur pengenaan dan pemungutan pajak (Lumbantoruan,1994). Administrasi pajak yang baik akan mempermudah wajib pajak untuk memenuhi kewajiban pajaknya. Komponen administrasi pajak yang terdiri dari kelengkapan instruksi dan kemudahan dalam ESPT dan E-filling akan mempengaruhi kepatuhan wajib pajak. Carolina (2011) dan Hardiningsih (2006) menemukan bahwa administrasi pajak berpengaruh terhadap perilaku wajib pajak dalam membayar sedangkan kemampuan membayar di pengaruhi oleh kondisi keuangan perusahaan (Bradley, 1994). Semakin lengkap instruksi yang termuat dalam formulir dan kemudahan dalam mengakses E-filling dan E-SPT, maka wajib pajak akan menimbulkan kemauan membayar yang akan meningkatkan kepatuhan wajib pajak. Sebaliknya, semakin kurang lengkap instruksi yang disajikan, maka wajib pajak semakin tidak patuh. Penjelasan yang dipaparkan secara lengkap pada formulir pajak akan memudah-kan wajib pajak untuk memahami isi dan melaksanakannya. Instruksi yang disajikan secara lengkap dan mudah dimengerti akan memudahkan wajib pajak untuk melaksanakan kewajiban perpajakannya. Berdasarkan tinjauan teori dan hasil penelitian sebelumnya dapat dirumuskan hipotesis penelitian sebagai berikut :

Hipotesis 1 : Administrasi perpajakan berpengaruh signifikan terhadap perilaku wajib pajak

\section{b. Kualitas Layanan terhadap Perilaku Wajib Pajak}

Memuaskan pelanggan adalah salah satu tujuan utama dari setiap bisnis, sedangkan konsep pelayanan dalam publik maupun privat banyak di definisikan oleh para ahli yang pada prinsipnya memberikan tekanan yang sama. Berkaitan dengan pelayanan kepada masyarakat, pemerintah harus mempersiapkan seluruh aparatnya untuk meningkatkan kualitas pelayanan bagi masyarakat. Kemampuan aparat merupakan syarat mutlak untuk menjaga citra instansinya, oleh karena itu perlu dijaga agar jangan terjadi hal-hal yang bisa mengangu tingkat kepuasan masyarakat yang dilayani.

Penelitian yang dilakukan oleh Athanassopoulos (2001), menyata-kan bahwa dengan adanya layanan yang baik maka akan meningkatkan keinginan pelanggan untuk menggunakan jasa layanan yang telah ada. Sedangkan Parvez (2009) menemukan dalam penelitiannya yakni dengan adanya kepuasan pelanggan maka akan meningkatkan loyalitas pelanggan. Berdasarkan tinjauan teori dan hasil penelitian sebelumnya dapat dirumuskan hipotesis penelitian sebagai berikut : 
Hipotesis 2: Kualitas layanan berpengaruh signifikan terhadap perilaku wajib pajak.

\section{c. Perilaku Wajib Pajak terhadap Kepatuhan Wajib Pajak}

Perilaku menurut Gibson et al (1996) menyatakan bahwa perilaku individu adalah segala sesuatu yang dilakukan oleh seseorang. Sedangkan menurut Kurt Levin (1996) juga menyatakan perilaku pada dasarnya merupakan fungsi dari interaksi antar personal dengan lingkungan.

Berdasarkan tinjauan teori dan hasil penelitian sebelumnya dapat dirumuskan hipotesis penelitian sebagai berikut :

Hipotesis 3: Perilaku wajib pajak berpengaruh signifikan terhadap kepatuhan wajib pajak.

\section{d. Administrasi Perpajakan terhadap Kepatuhan Wajib Pajak}

Administrasi

perpajakan

(tax

administration) adalah cara-cara atau prosedur pengenaan dan pemungutan pajak (Lumbantoruan, 1994). Administrasi pajak terdiri dari yaitu kelengkapan instruksi, kerumitan formulir, E-SPT, E-Filing, yang dimana disini sejauh mana pemahaman wajib pajak terhadap administrasi perpajakan. Kelengkapan instruksi berkaitan dengan penyajian instruksi yang terdapat dalam formulir yang harus diisi oleh wajib pajak ketika melaporkan pajaknya. Instruksi yang lengkap dapat membantu wajib pajak untuk memahami tata cara pengisian formulir secara tepat, sehingga dapat meminimalkan kesalahan wajib pajak. Kerumitan formulir berkaitan dengan tingkat kesulitan pengisian formulir.

Suandy (2003), Nasucha (2003) dalam Gunadi (2004) menyatakan bahwa terdapat tiga unsur-unsur perpajakan yang dapat menimbulkan tax gap dan perencanaan pajak, yaitu administrasi pajak dan kualitas layanan. Hal tersebut menjelaskan bahwa administrasi pajak, kualiats layanan memiliki peran penting dalam membentuk kepatuhan wajib pajak. Dalam penelitiannya Hardika (2006) menyatakan bahwa hanya peraturan pajak dan administrasi pajak yang berpengaruh terhadap kepatuhan wajib pajak, sedangkan kebijakan pajak tidak berpengaruh terhadap wajib pajak. Jadi dengan adanya administrasi perpajakan yang baik dan mudah di pahami maka akan mempengaruhi kepatuhan wajib pajak. Berdasarkan tinjauan teori dan hasil penelitian sebelumnya dapat dirumuskan hipotesis penelitian sebagai berikut :
Hipotesis 4 : Administrasi perpajakan berpengaruh signifikan terhadap kepatuhan wajib pajak.

\section{e. Administrasi Perpajakan terhadap Kepatuhan Wajib Pajak}

Administrasi perpajakan (tax

administration) adalah cara-cara atau prosedur pengenaan dan pemungutan pajak (Lumbantoruan, 1994). Administrasi pajak terdiri dari yaitu kelengkapan instruksi, kerumitan formulir, E-SPT, E-Filing, yang dimana disini sejauh mana pemahaman wajib pajak terhadap administrasi perpajakan. Kelengkapan instruksi berkaitan dengan penyajian instruksi yang terdapat dalam formulir yang harus diisi oleh wajib pajak ketika melaporkan pajaknya. Instruksi yang lengkap dapat membantu wajib pajak untuk memahami tata cara pengisian formulir secara tepat, sehingga dapat meminimalkan kesalahan wajib pajak. Kerumitan formulir berkaitan dengan tingkat kesulitan pengisian formulir.

Suandy (2003), Nasucha (2003) dalam Gunadi (2004) menyatakan bahwa terdapat tiga unsur-unsur perpajakan yang dapat menimbulkan tax gap dan perencanaan pajak, yaitu administrasi pajak dan kualitas layanan. Hal tersebut menjelaskan bahwa administrasi pajak, kualiats layanan memiliki peran penting dalam membentuk kepatuhan wajib pajak. Dalam penelitiannya Hardika (2006) menyatakan bahwa hanya peraturan pajak dan administrasi pajak yang berpengaruh terhadap kepatuhan wajib pajak, sedangkan kebijakan pajak tidak berpengaruh terhadap wajib pajak. Jadi dengan adanya administrasi perpajakan yang baik dan mudah di pahami maka akan mempengaruhi kepatuhan wajib pajak. Berdasarkan tinjauan teori dan hasil penelitian sebelumnya dapat dirumuskan hipotesis penelitian sebagai berikut :

Hipotesis 4 : Administrasi perpajakan berpengaruh signifikan terhadap kepatuhan wajib pajak.

\section{Model Konseptual}

Model konseptual dapat disajikan pada gambar 1 :

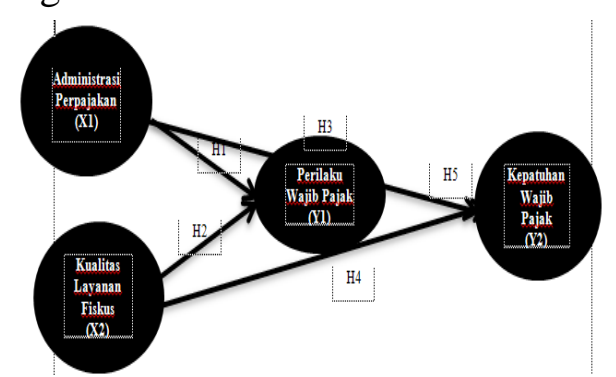

Gambar 1. Model konseptual 


\section{Metode Penelitian}

Penelitian ini menggunakan pendekatan kuantitatif dimana peneliti mengumpulkan data dengan terlebih dahulu dan menetapkan konsep sebagai variabel-variabel yang berhubungan yang bersumber dari teori yang sudah ada selanjutnya diturunkan menjadi hipotesis penelitian di sertai dengan peng-ukuran dan operasional variabel. Pendekatan kuantitatif dilandasi pada asumsi bahwa suatu gejala itu dapat diklasifikasikan, dan hubungan gejala bersifat kausal (sebab akibab) antar variabel konstruk melalui pengujian hipotesis (Sugiyono, 2011).

Penelitian ini adalah penelitian eksplanatori, yang dilakukan untuk menjelaskan fenomena yang terjadi. Menurut Sugiyono (2003) penelitian eksplanatori adalah penelitian yang bermaksud menjelaskan kedudukan variabelvariabel yang diteliti serta pengaruh antara satu variabel dengan variabel yang lain.

Lokasi penelitian dilakukan di Kota Malang Provinsi Jawa Timur.

\section{Hasil dan Pembahasan}

\begin{tabular}{|c|c|c|c|c|c|}
\hline $\mathrm{H}$ & Variabel bebas & $\begin{array}{l}\text { Variabel } \\
\text { terikat }\end{array}$ & Beta & Sig & Keterangan \\
\hline 1 & $\begin{array}{l}\text { Administrasi } \\
\text { perpajakan (X1) }\end{array}$ & $\begin{array}{l}\text { Perilaku wajib } \\
\text { pajak (Y1) }\end{array}$ & 0,450 & 0,000 & Signifikan \\
\hline 2 & $\begin{array}{l}\text { Kualitas layanan } \\
\text { fiskus (X2) }\end{array}$ & $\begin{array}{l}\text { Perilaku wajib } \\
\text { pajak (Y1) }\end{array}$ & 0,396 & 0,001 & Signifikan \\
\hline 3 & $\begin{array}{l}\text { Administrasi } \\
\text { perpajakan }(\mathrm{X} 1)\end{array}$ & $\begin{array}{l}\text { Kepatuhan } \\
\text { wajib pajak } \\
(\mathrm{Y} 2)\end{array}$ & 0,292 & 0,032 & Signifikan \\
\hline 4 & $\begin{array}{l}\text { Kualitas layanan } \\
\text { fiskus (X2) }\end{array}$ & $\begin{array}{l}\text { Kepatuhan } \\
\text { wajib pajak } \\
(\mathrm{Y} 2)\end{array}$ & 0,270 & 0,041 & Signifikan \\
\hline 5 & $\begin{array}{l}\text { Perilaku wajib } \\
\text { pajak (Y1) }\end{array}$ & $\begin{array}{l}\text { Kepatuhan } \\
\text { wajib pajak } \\
\text { (Y2) }\end{array}$ & 0,294 & 0,035 & Signifikan \\
\hline
\end{tabular}

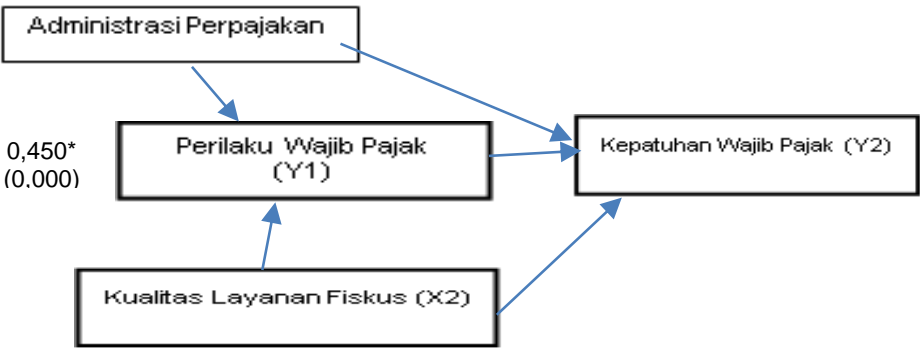

Gambar 2. Diagram jalur

\section{Pengujian hipotesis 1}

Hipotesis pertama (H1) yang menyatakan bahwa Administrasi perpajakan berpengaruh signifikan terhadap perilaku wajib pajak dapat diterima. Hal ini dibuktikan oleh hasil uji regresi nilai probabilitas sebesar 0.000 lebih kecil dari signifikansi 0.05 , menunjukkan hasil yang signifikan. Artinya administrasi perpajakan mempunyai pengaruh yang signifikan terhadap perilaku wajib pajak. Hasil uji statistik deskriptif juga menunjukkan bahwa skor rata-rata variabel Administrasi perpajakan sebesar 4.07 dan perilaku wajib pajak 4.51 yang termasuk dalam kategori tinggi. Hal ini mendukung bahwa administrasi perpajakan yang bagus akan meningkatkan perilaku wajib pajak. Indikator Kelengkapan instruksi (X1.1) memiliki skor rata-rata 3.93, termasuk dalam kategori tinggi. Item Instruksi yang termuat dalam peraturan pajak sudah sangat jelas dan terperinci (X1.1.1) terdapat 33 menjawab setuju dan 12 menjawab sangat setuju. artinya wajib pajak secara keseluruhan memahami intruksi yang tertulis dalam formulir perpajakan. Item

Koefisien jalur (beta) sebesar 0,450 yang mengindikasikan bahwa pengaruh administrasi perpajakan terhadap perilaku wajib pajak adalah positif. Artinya, semakin baik dan mudah administrasi perpajakan yang di tetapkan oleh pemerintah maka semakin bagus perilaku wajib pajak.

Hasil penelitian ini mendukung penelitian yang dilakukan oleh Carolina (2011) dan Hadiningsih (2006) menemukan bahwa administrasi berpengaruh terhadap perilaku wajib pajak dalam membayar sedangkan kemampuan membayar sangat di pengaruhi oleh kondisi keuangan perusahaan (Bradley, 1994).

\section{Pengujian hipotesis 2}

Hipotesis kedua $(\mathrm{H} 2)$ yang menyatakan bahwa Kualitas layanan fiskus berpengaruh terhadap perilaku wajib pajak dapat diterima. Hal ini dibuktikan oleh uji regresi nilai probabilitas 0,000 lebih kecil dari signifikansi 0,05, menunjukkan hasil yang signifikan. Artinya kualitas layanan fiskus mempunyai pengaruh yang signifikan terhadap perilaku wajib pajak. Hasil uji statistik deskriptif juga menunjukkan bahwa skor rata-rat variabel kualitas layanan fiskus sebesar 4.25 dan variabel 4.51 yang termasuk dalam kategori tinggi. Hal ini mendukung bahwa kualitas layanan yang baik akan mempengaruhi perilaku wajib pajak dan begitu juga sebaliknya.

Koefisien jalur (beta) sebesar 0,396 dan probabilitas sebesar 0,000 hal ini yang mengindikasikan bahwa pengaruh kualitas layanan fiskus terhadap perilaku wajib pajak adlah positif. Artinya semakin tinggi persepsi wajib pajak terhadap kualitas layanan fiskus maka akan semakin tinggi pula persepsi fiskus terhadap perilaku wajib pajak dalam memenuhi kewajibannya. Penelitian ini 
sesuai dengan Perspektif TQM (total quality management) kualitas dipandang secara lebih luas, yaitu tidak hanya aspek hasil yang ditekankan, tetapi juga meliputi proses, lingkungan dan manusia. Hal ini nampak jelas dalam definisi yang dirumuskan oleh Tjiptono (2000) bahwa kualitas merupakan suatu kondisi dinamis yang berhubungan dengan produk, jasa, manusia, proses, dan lingkungan yang memenuhi atau melebihi harapan.

Caro \& Garcia (2007) menunjuk-kan bahwa indikator kualitas layanan ditentukan oleh tiga faktor yaitu kualitas interaksi, kualitas lingkung fisik, dan hasil kualitas layanan. Yang dimaksud dengan kualitas interaksi yaitu bagaimana cara fiskus dalam mengomunikasikan pelayanan pajak kepada wajib pajak sehingga wajib pajak puas terhadap pelayanannya. Kualitas lingkungan fisik yang dimaksud adalah bagaimana peranan kualitas lingkungan dari kantor pajak sendiri dalam melayani wajib pajak.

Penelitian yang dilakukan oleh Athanassopoulos (2001), menyata-kan bahwa dengan adanya layanan yang baik maka akan meningkatkan keinginan pelanggan untuk menggunakan jasa layanan yang telah ada. Sedangkan Parvez (2009) menemukan dalam penelitiannya yakni dengan adanya kepuasan pelanggan maka akan meningkatkan loyalitas pelanggan.

\section{Pengujian hipotesis 3}

Hipotesis ketiga $(\mathrm{H} 3)$ yang menyatakan bahwa Administrasi perpajakan berpengaruh signifikan terhadap kepatuhan wajib pajak dapat diterima. Hal ini dibuktikan oleh hasil uji regresi nilai probabilitas 0,000 karena lebih kecil dari nilai signifikansi 0,05, hal ini menunjukkan hasil yang signifikan. Artinya administrasi perpajakan mempunyai pengaruh yang signifikan terhadap kepatuhan wajib pajak. Hasil uji statistic deskriptif juga menunjukkan bahwa skor rata-rata variabel administrasi perpajakan 4.07 dan variabel kepatuhan wajib pajak 4.45 yang termasuk dalam kategori tinggi. Hal ini mendukung bahwa administrasi perpajakan yang mudah di pahami, dimengerti dan dilaksanakan akan meningkatkan kepatuhan wajib pajak.

Koefisien jalur (beta) sebesar 0,292 yang mengindikasikan bahwa pengaruh administrasi perpajakan terhadap kepatuhan wajib pajak adalah positif. Artinya semakin tinggi persepsi wajib pajak terhadap administrasi perpajakan yang baik, mudah dipahami, dimengerti, dilaksanakan maka akan meningkatkan kepatuhan wajib pajak secara keseluruhan. Hasil penelitian ini sesuai dengan penelitian yang dikemukakan oleh Suandy (2003), Nasucha (2003) dalam Gunadi (2004) menyatakan bahwa terdapat tiga unsur-unsur perpajakan yang dapat menimbulkan tax gap dan perencanaan pajak, yaitu administrasi pajak dan kualitas layanan. Hal tersebut menjelaskan bahwa administrasi pajak, kualiats layanan memiliki peran penting dalam membentuk kepatuhan wajib pajak. Dalam penelitiannya Hardika (2006) menyatakan bahwa hanya peraturan pajak dan administrasi pajak yang berpengaruh terhadap kepatuhan wajib pajak, sedangkan kebijakan pajak tidak berpengaruh terhadap wajib pajak.

\section{Pengujian hipotesis 4}

Hipotesis keempat (H4) yang menyatakan bahwa Kualitas layanan fiskus berpengaruh terhadap kepatuhan wajib pajak dapat diterima. Hal ini dibuktikan oleh hasil uji regresi nilai probabilitas 0,000 karena lebih kecil dari nilai signifikansi 0,05, hal ini menunjukkan hasil yang signifikan. Artinya kualitas layanan fiskus mempunyai pengaruh yang signifikan terhadap kepatuhan wajib pajak. Hasil uji statistik deskriptif juga menunjukkan bahwa skor rata-rata variabel kualitas layanan fiskus sebesar 4.51 dan kepatuhan wajib pajak 4.45 yang termasuk dalam kategori tinggi. Hal ini mendukung bahwa kualitas layanan fiskus yang tinggi akan menghasilkan kepatuhan wajib pajak yang meningkat. Dan begitu juga sebaliknya apabila kualitas layanan fiskus rendah maka dapat menurunkan tingkat kepatuhan wajib pajak.

Koefisein jalur (beta) sebesar 0.294 yang mengindikasikan bahwa pengaruh kualitas layanan terhadap kepatuhan wajib pajak adalah positif. Artinya semakin tinggi persepsi wajib pajak terhadap kualitas layanan fiskus maka akan semakin tinggi tingkat kepatuhan wajib pajak. Hasil penlitian ini sesuai dengan hasil penelitian yang dilakukan oleh Puspita (2012) menyatakan bahwa kualitas layanan merupakan faktor penting yang dapat membentuk perencanaan pajak dan kepatuhan wajib pajak. Akan tetapi hasil penelitian Siahaan (2012) menemukan bahwa tidak ada pengaruh antar kualitas layanan aparat pajak dengan kepatuhan wajib pajak.

\section{Pengujian hipotesis 5}

Hipotesis kelima (H5) yang menyatakan bahwa perilaku wajib pajak berpengaruh terhadap kepatuhan wajib pajak dapat diterima. Hal ini dibuktikan oleh hasil uji regresi nilai probabilitas 0,000 karena lebih kecil dari nilai signifikansi 0,05, hal ini menunjukkan hasil yang signifikan. Artinya perilaku wajib pajak berpengaruh yang signifikan terhadap kepatuhan wajib pajak. Hasil uji statistik 
deskriptif juga menunjukkan bahwa skor rata-rata variabel perilaku wajib pajak sebesar 4.51 dan variabel kepatuhan wajib pajak 4.45 yang termasuk dalam kategori tinggi. Hal ini mendukung bahwa perilaku wajib pajak yang tinggi akan meningkatkan kepatuhan wajib pajak.

Koefisien jalur (beta) sebesar 0,270 yang mengindikasikan bahwa pengaruh perilaku wajib pajak terhadap kepatuhan wajib pajak adalah positif. Artinya semakin tinggi persepsi tentang perilaku wajib pajak yang bagus akan mempengaruhi tingkat kepatuhan wajib pajak. Hal ini sesuai dengan pendapat Gibson et al (1996) menyatakan bahwa perilaku individu adalah segala sesuatu yang dilakukan oleh seseorang. Sedangkan menurut Kurt Levin (1996) juga menyatakan perilaku pada dasarnya merupakan fungsi dari interaksi antar personal dengan lingkungan.

Gibson (1987) juga menyatakan variabelvariabel yang mempengaruhi perilaku individu antara lain yakni variabel kemampuan dan kemauan, latar belakang pribadi dan demografis. Variabel kemampuan dan kemauan merupakan faktor utama yang mempengaruhi perilaku kerja dan kinerja individu, sedangkan variabel demografis mempunyai pengaruh tidak langsung.

\section{Simpulan}

Berdasarkan hasil analisis data penelitian baik secara deskriptif maupun secara inferensial yang telah dilakukan terhadap teoritis dan model hipotesis penelitian ini, maka dapat disimpulkan sebagai berikut :

1. Administrasi perpajakan ber-pengaruh positif dan signifikan terhadap perilaku wajib pajak. Hasil pengujian ini Artinya administrasi perpajakan mem-punyai pengaruh yang signifikan terhadap perilaku wajib pajak. Hasil uji statistik deskriptif juga menunjukkan bahwa skor rata-rata variabel Administrasi perpajakan sebesar 4.07 dan perilaku wajib pajak 4.51 yang termasuk dalam kategori tinggi. Hal ini mendukung bahwa administrasi perpajakan yang bagus akan meningkatkan perilaku wajib pajak.

2. Kualitas layanan fiskus terbukti berpengaruh positif dan signifikan terhadap perilaku wajib pajak. Artinya kualitas layanan fiskus mempunyai pengaruh yang signifikan terhadap perilaku wajib pajak. Hasil uji statistik deskriptif juga menunjukkan bahwa skor ratarat variabel kualitas layanan fiskus sebesar 4.25 dan variabel 4.51 yang termasuk dalam kategori tinggi. Hal ini mendukung bahwa kualitas layanan yang baik akan mempengaruhi perilaku wajib pajak dan begitu juga sebaliknya.

3. Perilaku wajib pajak terbukti berpengaruh positif dan signifikan terhadap kepatuhan wajib pajak. Artinya perilaku wajib pajak berpengaruh yang signifikan terhadap kepatuhan wajib pajak. Hasil uji statistik deskriptif juga menunjukkan bahwa skor ratarata variabel perilaku wajib pajak sebesar 4.51 dan variabel kepatuhan wajib pajak 4.45 yang termasuk dalam kategori tinggi. Hal ini mendukung bahwa perilaku wajib pajak yang tinggi akan meningkatkan kepatuhan wajib pajak.

4. Administrasi perpajakan terbukti berpengaruh positif dan signifikan terhadap kepatuhan wajib pajak. Artinya administrasi perpajakan mempunyai pengaruh yang signifikan terhadap kepatuhan wajib pajak. Hasil uji statistic deskriptif juga menunjukkan bahwa skor ratarata variabel administrasi perpajakan 4.07 dan variabel kepatuhan wajib pajak 4.45 yang termasuk dalam kategori tinggi. Hal ini mendukung bahwa administrasi perpajakan yang mudah di pahami, dimengerti dan dilaksanakan akan meningkat-kan kepatuhan wajib pajak.

5. Kualitas layanan fiskus terbukti berpengaruh positif dan signifikan terhadap kepatuhan wajib pajak. Artinya kualitas layanan fiskus mempunyai pengaruh yang signifikan terhadap kepatuhan wajib pajak. Hasil uji statistik deskriptif juga menunjukkan bahwa skor ratarata variabel kualitas layanan fiskus sebesar 4.51 dan kepatuhan wajib pajak 4.45 yang termasuk dalam kategori tinggi. Hal ini mendukung bahwa kualitas layanan fiskus yang tinggi akan menghasilkan kepatuhan wajib pajak yang meningkat. Dan begitu juga sebaliknya apabila kualitas layanan fiskus rendah maka dapat menurunkan tingkat kepatuhan wajib pajak.

\section{Saran}

Dari hasil penelitian, diajukan beberapa saran yang bisa digunakan sebagai bahan pertimbangan bagi peneliti lain dalam bidang perpajakan yang akan melakukan penelitian lanjutan.

1. Peneliti selanjutnya perlu mengkaji lebih dalam tentang variabel kepatuhan wajib pajak meng-gunakan teori yang lain dari para ahli dengan indikator yang berkaitan dengan kepercayaan, keinginan dan 
perencanaan pajak yang dapat meningkatkan kepatuhan wajib pajak badan.

2. Peneliti yang selanjutnya perlu mengkaji lebih dalam lagi untuk menggunakan teori perilaku yang lain dengan indikator yang perlu penyesuaian yang di pakai sebagai dasar menilai kepatuhan wajib pajak.

3. Pengumpulan data pada penelitian mendatang dirasa perlu menggunakan instrument selain angket/kuesioner seperti wawancara langsung kepada responden.

4. Penelitian selanjutnya dapat melakukan penelitian terhadap wajib pajak berdasarkan jenis usaha, skala usaha, sehingga dapat diketahui perbedaan pemahaman wajib pajak terhadap aturan, layanan, fasilitas yang diberikan oleh fiskus.

\section{Daftar Pustaka}

[1] Abimanyu, Anggito. 2004. Wajib Pajak Belum Patuh. http:/fiscal.depkeu.go.id/pemik. Html. Desember 2008.

[2] Agus Nugroho Jatmiko (2006). Pengarih Sikap Wajib Pajak pada Pelaksanaan Sanksi Denda, Pelayanan Fiskus dan Kesadaran Perpajakan Ter-hadap Kepatuhan Wajib Pajak Studi Empiris Terhadap Wajib Pajak Orang Pribadi di Kota Semarang. Universitas Diponegoro: Tesis Magister Akuntansi.

[3] Ajzen, I., (2005). Attitudes, Personality, and Behavior. New York: Open University Press

[4] Ajzen, Icek, (1991), The Theory of Planned Behavior, Organi-zational Behavior and Human Decision Process, Vol. 50, pp. 179211.

[5] Ajzen, I. \& Fishbein, M. (1980). Understanding Attitudes and Predicting Social Behavior. Englewood Cliffs, NJ: Prentice Hall.

[6] Alm. J., (1998). Tax Compliance and Administration. Centre for Economic Analysis. Dept. of Economics, University Press.

[7] Andirana, Ateng. (2011). Analisis Atas Penerapan Self Assessment System dan Kualitas Pelayanan Pajak Terhadap Peningkatan Kepatuhan Formal Wajib Pajak Pada KPP Pratama Kota Bandung

[8] Anonim, Undang-undang Republik Indonesia Nomor 17 Tahun 2000 tentang Perubahan Ketiga Atas Undang-undang Nomor 7 Tahun 1983 tentang Pajak Penghasilan, PT Mitra Info, Jakarta.
[9] Antreas Athanassopoulus, Spiros Gounaris, Vlassis Statha-kopoulos, (2001) "Behavioural Responses to Customer Satis-faction: an empirical study", European Journal of Marketing, Vol. 35 Iss: 5/6, pp. 687-707

[10] Arikunto, 1993, Prosedur Penelitian, Suatu Pendekatan Praktek, Edisi Kesembilan, Rineka Cipta, Jakarta.

[11] Arniati. 2009. Peran Theory of Planned Behavior Terhadap Ketaatan Wajib Pajak. Seminar Nasional Perpajakan II. Universitas Trunojoyo. Madura.

[12] Ayu, Puri Puspita. 2012. Pengaruh Motivasi Perencanaan Pajak, Pembelajaran, Kualitas Layanan Aparat Pajak, Persepsi Keadilan Sistem Pajak yang Dimediasi oleh Variabel Perencanaan Pajak Terhadap Kepatuhan Wajib Pajak. Universitas Brawijaya Malang: Tesis Magister Akuntansi.

[13] Bird, R.M. dan Vaillancourtf, F. (2000). Desentralisasi Fiskal di Negara-negara Berkembang. Jakarta: PT. Gramedia Pustaka Utama.

[14] Boediono, B. 2003. Pelayanan Prima Perpajakan. Rineka Cipta: Jakarta.

[15] Bradley, Cassie Francies. 1994. An Empirical Investigation Of Factors Affecting Corporate Tax Compliance Behavior. Dis-sertation. The University of Alabama. Pp 1-128

[16] Caro, L. M., \& Garcia, J.A.M. (2007). Cognitive-affective Model of Consumer Satisfaction. An Exploratory Study Within the Framework of a Sporting Event. Journal of Business Research, 60, 108-114.

[17] Chau, Gerald, Patrick Leung, (2009), "Critical Review og Fischer Tax Compliance Model" A Research Synthesis" Journal of Accounting and Taxation, Vol. 1, pp. 0341-040.

[18] Clotfelter. Charles T. 1983. Tax Evasion and Tax Rates : An analysis of individual Return. The Review of Economics Statistics Vol. 63 No. 3 Pp. 363-373

[19] Devos, Ken (2008) "Tax Evasion Behaviour and Demographic Faktors: An Exploratory Study in Australia," Revenue Law Journal: Vol. 18: Iss. 1. Article 1.

[20] Erly Suandi, 2001. Perencanaan Pajak, Jakarta: Salemba Empat.

[21] Fadjar Siahaan. 2005. Faktor-faktor yang Mempengaruhi Perilaku Tax Profesional dalam Pelaporan Pajak Badan Pada Perusahaan Manufaktur di Surabaya.

[22] Ferdinand, Augusty. 2006. Metode Penelitian Manajemen. Badan Penerbit Universitas Dipenogoro, Semarang. 
[23] Firmanzah, 2013. Prakiraan Perekonomian Indonesia 2013 ,Staf Khusus Presiden Bidang Ekonomi dan Pembangunan, Desember 2012.

[24] Gary Amstrong and Philip Kotler (2001, Paperback), Principles of Marketing Prentice Hall PTR.

[25] Gunadi. 2004. "Rasionalitas Reformasi Administrasi Per-pajakan" http://www. infopajak. com/berita///170504bi1.htm

[26] Handayani, Ririn. 2006. Hubungan Tax Ratio Dengan Kemandirian Bangsa. Direktorat Jenderal Pajak Departemen Keuangan Republik Indonesia.

[27] Hadipurnomo, Tidar. 2003. Penghindaran Pajak Optimal Versus Penetapan Pajak Optimal. http://tumoutou. net/ 702_07134/tidar_hadipurnomo.pdf

[28] Hutagaol, John. 2007. Sudah Saatnya Wajib Pajak Bicara. Indonesian Tax Review Volume VI, Edisi 26/2007

[29] Hardika, Nyoman Sentosa. 2006. Pengaruh Lingkungan dan Individu Wajib Pajak terhadap Kepatuhan Wajib Pajak Pada Hotel Berbintang di Provinsi Bali. Disertasi Universitas Airlangga Surabaya.

[30] Harahap, Sofyan Syafri. 2004. Akuntansi Aktiva Tetap, Edisi Ketiga, Jakarta: Penerbit PT. Raja Grafindo.

[31] Hidayat, Widi dan Argo Adhi Nugroho. 2010. Studi Empiris Theory of Planned Behavior dan Pengaruh Kewajiban Moral pada Perilaku Keditapatuhan Pajak Wajib Pajak Orang Pribadi. Jurnal Akuntansi dan Keuangan. Vol. 12. No. 2 Hal. 82-93.

[32] Ilyas Wirawan B. (2001). "Hukum Pajak", Salemba Empat, Jakarta.

[33] Inamullah Khan (2012). Impact of Customers Satisfaction and Customers Retention on Customer Loyalty, International Journal of Scientific \& Technology Research Volume 1, Issue 2, March 2012.

[34] Kirchler, E. (2007). The Economic Psychology of tax behaviour. Cambridge: Cambridge Univer-sity Press.

[35] Kotler, P. dan Keller, K.L. (2007). Manajemen Pemasaran, Edisi Kedua Belas Jilid 1. Edisi Bahasa Inggris. Pearson Education, Inc. Upper Saddler.

[36] Mardiasmo (2002), "Perpajakan", Edisi Revisi, Andy Yogyakarta, Yogyakarta.

[37] Michael Doran (2009). Tax Penaltied and Tax Compliance, Harvard Journal on Legislation Vol. 46, pp 111-161
[38] Mohammad Muzahid Akbar, and Noorjahan Parvez (2009). Impact of Service Quality, Trust, and Customer Satisfaction Engender Customer Loyalty, ABAC Journal Vol. 29, No. 1 (January-April 2009, pp. 24-38

[39] Muhammad Ahmad Raza (2012). Relationship Between Service Quality, Perceived Value, Satisfaction and Revisit Intention in Hotel Industry.

[40] Mustikasari, Elia (2007). Kajian Empiris tentang Kepatuhan Wajib Pajak Badan di Perusaha-an Industri, Pengolahan di Surabaya, Simposium Nasional Akuntansi X, Makasar.

[41] Nasucha, Chaizi. 2004. Repormasi Administrasi Publik: Teori dan Praktik. Gramedia Widiasarana Indonesia, Bandung.

[42] Novianto, Eko. 2008. Problem Kepercayaan Publik. http:// ekonov-perpajakan. blogspotcom/. Desember 2008.

[43] Nurmantu, Safri, 2003, Pengantar Perpajakan. Granit, Jakarta.

[44] Parasuraman, A. Zeithaml, W. and Berry L. (1985), “A Conceptual Model of Service Quality and its Implications for Future Research", Journal of Marketing, Vol. 49, pp. 41-50.

[45]

(1988). SERV-QUAL: A multiple tem scale for measuring consumer percep-tions of service quality. Journal of Retailing, 64 (1), pp.12-40.

[46] Rapina, Jerry dan Yenni Carolina, 2011. Pengaruh Penerapan Sistem Administrasi Perpajakan Modern Terhadap Kepatuhan Wajib Pajak (Survey Terhadap kantor Pelayanan Pajak Pratama Bandung Cibeunying). Jurnal Ristek Akuntansi Vol. III No. 2 Oktober 2011.

[47] Robbins, Stephen P. 2001. Organizational Behavior. Pren-tice Hall, New York.

[48] Sekaran, Uma. 2000. Research Methods for Business, A Skill-Building Approach. America: Third Edition, John Willy \& Sons, Inc.

[49] Singarimbun, Masri dan Sofian Effendi. 1995: Metode Penelitian Survey. Jakarta: PT. Pustaka LP3ES.

[50] Siahaan, Fajar OP. 2005. Faktor-faktor yang Mempengaruhi Perilaku Kepatuhan Tax Professional dalam Pelaporan Pajak Badan pada Perusahaan Industri Manufaktur di Surabaya.Disertasi Universitas Airlangga Surabaya. 
74 JIAP | Jurnal IImu Administrasi Publik | Vol. 6, No. 1, Bulan Maret Tahun 2018

[51] Skaran, Huma, (2006). Metode Penelitian Bisnis, Jakarta, Salemba Empat.

[52] Soemitro, Rochmat dan Dewi Kania Sugiharti. 2004. Asas dan Dasar Perpajakan. PT Refika Aditama, Bandung.

[53] Suandy, Erly, 2001. Perencanaan Pajak. Jakarta: Salemba Empat.

[54] Sugiyono, (2008). Metode Penelitian Bisnis. Bandung: Penerbit Alfabeta

[55] Sugiyono, (2007). Metode Penelitian. Bandung: Alfabeta.

[56] Tjiptono Fandy. (1997). Prinsip-prinsip Total Quality Service (TQS). Yogyakarta: Andi

[57] Waluyo, (2005), "Perpajakan Indonesia", Edisi Revisi, Jakarta.

[58] Waluyo, (2008), "Perpajakan Indonesia, Jakarta: Salemba Empat

[59] Yoeti, H. Oka. 2000. Customer Service (Cara Efektif Memuaskan Pelanggan). Jakarta: PT. Pradnya Paramita.

[60] Yurzal, (2002), Analisis Perilaku Wajib Pajak Berdasarkan Pendekatan Wajib Pajak, Berita Pajak No. 1463, Jakarta.

[61] Zaine, Abdullah (2001), substansi Konsep Undang-undang Saidi, Muhammad Djafar. 2011. Hukum Keuangan Negara. Rajawali Pers:Jakarta.

[62] Semedi, Bambang. 2013. Pengawasan Kepabeanan. Widyaiswara Pusdiklat Bea dan Cukai:Jakarta.

[63] Siagiaan, S.P. 1980. Administrasi Pembangunan. PT. Gunung Agung: Jakarta.

[64] Situmorang, Victor. 1998. Aspek Hukum Pengawasan Melekat dalam Lingkungan Aparatur Pemerintah. Rineka Cipta:Jakarta.

[65] Sugiyono, Prof. Dr. 2017. Metode Penelitian Kuantitatif dan Kualitatif, dan R\&D. Alfabeta,cv : Jakarta.

[66] Sutarto, Eddhi. 2010. Rekonstruksi Sistem Hukum Pabean Indonesia. Erlangga: Jakarta.

[67] Sutedi, Adrian. 2012. Aspek Hukum Kepabeanan. Sinar Grafika: Jakarta

\section{Artikel/Modul/Diktat:}

[1] Undang-undang Nomor 17 tahun 2006 tentang Perubahan Atas Undang Undang Nomor 10 tahun 1995 tentang Kepabeanan

[2] Instruksi Presiden Republik Indonesia Nomor 1 Tahun 1989 Tentang Pedoman Pelaksanaan Pengawasan Melekat

[3] Peraturan Menteri Keuangan Nomor 203/PMK.04/2017 tentang Ketentuan Ekspor dan Impor Barang yang dibawa oleh Penumpang dan Awak Sarana Pengangkut
[4] Peraturan Direktur Jenderal Bea dan Cukai Nomor : Per-16/BC/2016 Tentang Petunjuk Pengeluaran Barang Impor Untuk dipakai

[5] Peraturan Menteri Keuangan Nomor 182/PMK.04/2016 tentang Ketentuan Impor barang Kiriman

[6] Peraturan Menteri Keuangan Nomor 131/PMK.01/2011 tentang Perubahan Kedua Atas Peraturan Menteri Keuangan Nomor 74/PMK.01/2009 Tentang Organisasi dan Tata kerja Instansi Vertikal Direktorat Jenderal Bea dan Cukai

[7] Direktur Jenderal Bea dan Cukai (2010). Peraturan Direktur Jenderal Bea dan Cukai Nomor P-53/ BC/2010 tentang Tata Laksana Pengawasan. 